open, more or less dry Picea glauca woodland with rich fens and dry sites. He concludes that today $95 \%$ of the Twocreekan moss flora is still present in the area or nearby.

\section{REFERENCES}

Black, R. F. (1966). Valders glaciation in Wisconsin and Upper Michigan-A progress report. In "Great Lakes Research Conference, 9th, Chicago, 1966, Proceedings,"' Publ. No. 15, pp. 169-175. University of Michigan, Great Lakes Research Division, Ann Arbor, Mich.

Black, R. F. (1970a). "Glacial Geology of Two Creeks Forest Bed, Valderan Type Locality, and Northern Kettle Moraine State Forest."'Wisconsin Geological and Natural History Survey Information Circular 13.

Black, R. F. (1970b). Chronology and Climate of Wisconsin and Upper Michigan-14,000 to 9,000 radiocarbon years ago. American Quaternary Association Abstracts, 12.

Black, R. F. (1974). Late Pleistocene shorelines and stratigraphic Relations in the Lake Michigan basin: Discussion. Geological Society of America Bulletin $85,659-670$.

Black, R. F. (1976). Quaternary Geology of Wisconsin and contiguous Upper Michigan. In "Quaternary Stratigraphy of North America" (W. C. Mahaney, Ed.), pp. 93-117. Dowden, Hutchinson, and Ross, Stroudsburg, Pa.

Black, R. F., and Reed, E. C. (1965). "Guidebook for Field Conference C, Upper Mississippi Valley", (C. B. Schultz and H. T. U. Smith, Eds.), International Association for Quaternary Research, VIIth Congress. The Nebraska Academy of Sciences, Lincoln, Neb.

Black, R. F., and Rubin, M. (1967-1968). Radiocarbon dates of Wisconsin. Wisconsin Academy of Science, Arts and Letters 56, 99-115.
Evenson, E. B., Farrand, W. R., Eschman, D. F., Mickelson, D. M., and Maher, L. J. (1976). "Greatlakean Substage: A Replacement for Valderan Substage in the Lake Michigan basin." Quaternary Research 6, 411-424.

Frye, J. C., and Willman, H. B. (1960). "Classification of the Wisconsinan Stage in the Lake Michigan Glacial Lobe." Illinois Geological Survey Circular 285.

Frye, J. C., Willman, H. B., and Black, R. F. (1965). Outline of glacial geology of Illinois and Wisconsin. In "The Quaternary of the United States" (H. E. Wright, Jr., and D. G. Frey, Eds.), pp. 43-61. Princeton University Press, Princeton, N. J.

Lineback, J. A., Gross, D. L., and Meyer, R. P. (1974). "Glacial Tills Under Lake Michigan." Illinois Geological Survey Environmental Geology Note 69.

Mickelson, D. M., and Evenson, E. B. (1975). PreTwocreekan age of the type Valders till, Wisconsin. Geology 3, 587-590.

Miller, N. G. (1976). Studies of North American Quaternary bryophyte subfossils. 1. A new moss assemblage from the Two Creeks forest bed of Wisconsin. In "Occasional Papers of the Farlow Herbarium of Harvard University" (Reed C. Rollins and Kathryn Ruby, Eds.), No. 9, pp. 2142. Cambridge, Mass.

Piette, C. R. (1963). “Geology of Duck Creek Ridges, East-Central Wisconin." Master's Thesis, 'The University of Wisconsin.

Suttner, L. J., (1963). "Geology of Brillion Ridge, East-Centtral Wisconsin.” Master's Thesis, The University of Wisconsin.

Thwaites, F. T. (1946). "Outline of Glacial Geology." Lithoprinted by the author. 129 pp. Madison, Wis.

ROBERT F. BLACK

Department of Geology and Geophysics The University of Connecticut Storrs, Connecticut 06268

\title{
Reply to Comments by P. F. Karrow and R. F. Black
}

It is encouraging to see that our article on the late Wisconsinan stratigraphy of the Lake Michigan Basin has been thought provoking, and we wish to thank Karrow and Black for their comments and we welcome the opportunity to discuss their replies.

Karrow's comments on our paper are, by his own definition (pers. commun., 1977) "mainly a voicing of opinions," and we share many of his feelings. While revising the nomenclature of this key area, we were besieged by many of the feelings that are expressed so succinctly by Karrow, and in many cases we originally entertained the same solutions. In our section on "Interpretation and Revision of Nomenclature" (pp. 417-420), we discussed some of the points raised by Karrow and presented our reasoning behind the final selections. 
We are in agreement with Karrow's statement that our demonstration of the lesser magnitude of ice retreat and advance during the Twocreekan and Greatlakean events reduces their importance relative to other substages of the Illinois State Geological Survey classification. However, we do not feel that, within the confines of tradition, the rules of priority, and the Code of Stratigraphic Nomenclature, we can justify the abandonment of substage rank for the Twocreekan and Greatlakean events as suggested by Karrow. For this reason, we elected to replace "Valderan" with "Greatlakean" at substage rank and retain, with minor redefinition, the existing and wellaccepted time-stratigraphic system of the Illinois State Geological Survey (Frye and Willman, 1960; Frye et al., 1968; Willman and Frye, 1970).

Karrow's comment that the St. Narcisse advance (LaSalle and Elson, 1975) may be post-Greatlakean in age is not likely to be correct. Although we do not claim that this advance either correlates with the Two Rivers advance (Evenson et al., 1976a, 1976b; Evenson et al., in press; Evenson and Dreimanis, 1976) or was emplaced during the same climatic event as was the Two Rivers moraine, it is unlikely that it is postGreatlakean. We place the end of the Greatlakean Substage (p. 419) between 8275 and $7000{ }^{14} \mathrm{C}$ years BP. Based on the available radiocarbon dates (i.e., LaSalle and Elson, 1975; Occhietti, 1972, 1974, 1976, pers. commun.; Prichonnet, 1976; Terasame and LaSalle, 1968) it appears that the St. Narcisse was emplaced sometime between 11,500 and $10,000{ }^{14} \mathrm{C}$ years BP. Even allowing for possible errors associated with dates obtained from marine shells, the event appears to fit comfortably within the Greatlakean Substage as defined in our paper.

We agree with Karrow that the Twocreekan time was short (sec p. 421) and, like him, accept 11,850 years $B P$ as the upper limit of the Twocreekan (see p. 418). $\mathrm{He}$ is correct in pointing out that bogbottom dates are not reliable indicators of the minimum age of ice retreat if they are contaminated by old carbon. If the Seidel Lake date $(11,620 \pm 110)$ is too old due to contamination, as he and Webb (pers. commun., 1977) suggest, it does not document the minimum age of deglaciation of the Seidel Lake site. However, as the Seidel Lake date has no direct bearing on our chronology or nomenclature, its contamination (increased age) would only mean that the Greatlakean ice retreated slightly more slowly than we have suggested.

Karrow's discussion of the problems associated with the selection of a time boundary for the end of the Greatlakean, and therefore of the placement of the Pleistocene-Holocene boundary, is informative. We recognize the problems and refer the reader to the last paragraph of his reply. We have not redefined this boundary (see p. 419) nor have we suggested that the end of the Greatlakean serve as an international stratotype for the boundary between the Pleistocene and Holocene. We have defined, following Willman and Frye (1970), a local time-stratigraphic boundary between the Greatlakean and the Holocene (see p. 419).

We thank Black for the completeness of his review of the literature pertinent to all aspects of the Valders question. Perhaps we were somewhat lax in omitting a thorough discussion of the published and unpublished work of Black and his students. We certainly regret that Black feels we did not give enough credit to his earlier studies. His early work in this area is well known to us and much of it is reviewed in our earlier papers (e.g., Evenson, 1973; Evenson et al., 1974; Mickelson and Evenson, 1975). Without the benefits of his earlier critical review (Black, 1974) of our work, we might not have undertaken some of the studies (e.g., Mickelson and Evenson, 1975) necessary to convince ourselves and many others of the appropriateness of our interpretations. However, Black's comment that we were "not alone" when we stated that "Evenson (1973a, b) and others (Lineback et al., 1974; Farrand, 1970; Farrand et al., 1969) have demonstrated the presence of 
pre- and post-Twocreekan red tills in the Lake Michigan basin, and Evenson (1973) suggested that the type Valders Till was pre-Twocreekan (Woodfordian) in age" is misleading. Although Black did describe pre- and post-Twocreekan tills, as he points out, he never suggested, and in fact has argued strongly against (Black, 1974) the concept, that the type-Valders Till (at Valders Quarry) and the red till along Lake Michigan between Manitowoc and Milwaukee is pre-Twocreekan.

We are pleased that Black agrees with our statement that the Cary-Port Huron (Mackinaw) interstade was much more significant than the Twocreekan interstade, and it is interesting to learn that CaryPort Huron retreat was extensive in northeastern Wisconsin as well as in Michigan and farther east. However, Black's indication that we based our conclusion only on evidence from the Cheboygan bryophyte bed locality is in error. There are a number of pertinent pieces of evidence other than the Cheboygan Bryophyte Bed; most of these were reviewed in the original bryophyte bed paper (Farrand et al., 1969), as well as in Dreimanis and Goldthwait (1973, p. 95) and Evenson and Dreimanis (1976, pp. 219220). Our paper in Quaternary Research, was not intended to be exhaustive on that subject. Black wonders, however, why no organic materials of Cary-Port Huron age have been found buried by the equivalent of the Port Huron advance in Wisconsin and seems to imply that this is a weakness in our interpretation. It should be clear to all Quaternary geologists that the lack of organic matter is not a substantial argument against our hypothesis. There are several reasons that could explain the paucity of organic material; first of all, there is much serendipity in geological field work. Recall that the Cheboygan County Bryophyte Bed is the unique occurrence known so far of organic materials below Port Huron till in spite of the fact that the Port Huron moraine and its equivalents can be traced for hundreds of kilometers in Wisconsin, Michigan, southern Ontario, and New York (Evenson and Dreimanis, 1976, Fig. 2). Recall further that pollen studies of the Cheboygan County locality indicate that the area was treeless and that forests were probably not growing within some $80 \mathrm{~km}$ of the site 13,000 years BP (Farrand et al., 1969, p. 256). This lack of trees close to the glacial front may account for the apparent absence of buried forests and of logs in drift of pre-Port Huron age. Black and Rubin (1967-68, p. 110) point out the scarcity of radiocarbon-dated material of Woodfordian age in Wisconsin, and yet they do not argue against Woodfordian ice activity in that area. Moreover, it is conceivable that there was no Port Huron readvance (necessary to bury and preserve organics of Cary-Port Huron age) in northern Wisconsin and western upper Michigan. It is also possible that deposits of this age have been buried by the subsequent Greatlakean advance (Evenson and Dreimanis, 1976, Fig. 2). We are becoming more and more aware that not all lobes along an ice front move with the same amplitude, speed, or timing, and this is especially true for lobes of rather different size. None of these factors, nor any of Black's arguments, are counter to our hypothesis nor do they explain the presence of the distinctive red tills (Mickelson and Evenson, 1975) cut by pre-Twocreekan shorelines (Evenson, 1973) documented by us on land and by Lineback (et al., 1974) in the Lake Michigan Basin. We have no argument with Black's statement that "differences in late Wisconsinan history exist between northern Wisconsin and upper Michigan on the one hand and lower Michigan on the other (Black, 1970b and 1976)" and, in fact, have come to a similar conclusion (Evenson and Dreimanis, 1976, Fig. 2).

We are in agreement with Black on the significance, duration, and termination of the Twocreekan interstade. We never stated or meant to imply that we disagreed with Black on this matter.

Black's apparently most substantive criticism centers on our modification of the interpretations (map) by Lineback et al. 
(1974). Black states that we made "major" modifications of this boundary, with "no specific justification," to support our "side of the debate." We do not agree that our modification is either major or unjustified. It should be pointed out that much of the evidence supporting our revision of this boundary has already been published in Evenson (1973), Evenson et al. (1974), and Mickelson and Evenson (1975). Black's statement appears not only to challenge our interpretations, but also our integrity. Therefore we will present, in some detail, the major justifications for our revision of the boundary of Lineback et al. (1974).

(1) According to Black, the pivotal piece of data is sample FOP-7 of Lineback et al. (1974, Fig. 4; Fig. 1, this paper; compare with Fig. 1, Black, 1978, and Fig. 1, Evenson et al., 1976a), interpreted by those authors as Two Rivers Till. (The other sample of Two Rivers Till (No. 903) in the lake, also implicated by Black, is perfectly concordant with our Two Rivers boundary, and the fact that thick till lies on bedrock south of Manitowoc is irrelevant unless the age of the till is specified. Sample FOP-7 is similar lithologically (our Table 1) to the Two Rivers Till (compare with Table 1, Lineback, 1974), but on the same basis it could just as well be Manitowoc till. There is hardly any difference between Two Rivers and Manitowoc tills (according to Lineback et al., 1974, Table 1) except that Manitowoc till has more dolomite than calcite. Because FOP-7 had 2 counts per second more calcite than dolomite, Lineback et al. (1974) placed it in the Two Rivers Till. Lineback averaged the composition of FOP-7 with two other samples assigned to the Two Rivers Till. If the contribution of FOP-7 is removed from this average and is then compared to the compositions of the new values for the Two Rivers Till (our Table 1) and the composition of the Manitowoc till, it is clear that no strong case can be made for placing this sample in either the Two Rivers or Manitowoc tills. However, the average composition of FOP-7 is closer, in all cases, to the composition of the Manitowoc till than it is to the Two Rivers Till. There is, of course, a problem associated with the grouping of samples when the sample size is very small, and we imply no criticism of the original grouping of Lineback et al. (1974).

(2) Moreover, the locality of sample FOP-7 lies in an area south of Manitowoc and the Two Rivers lowland where the Glenwood shoreline is well preserved and documented (Evenson, 1973; Evenson et al., 1974; Mickelson and Evenson, 1975), obviating the possibility of post-Glenwood till deposition at that spot. Because Two Rivers Till is post-Glenwood in age, sample FOP-7, cut by the Glenwood shoreline, must be pre-Two Rivers (Woodfordian) in age. The presence of Glenwood lacustrine deposits on top of the till referred to by Black has been documented by shoreline mapping (Evenson, 1973), by power auger borings west of the Two Rivers lowland (Mickelson and Evenson, 1975, p. 588), and by mapping conducted the past summer (1976) along the Lake Michigan bluffs (Mickelson et al., 1977).

(3) Depth of leaching measurements made by Mickelson and Evenson (1975) clearly demonstrate a distinct break between the Two Rivers Till and the older till near Manitowoc, as well as between tills of preand post-Twocreekan age in the Green Bay Lobe. Black has ignored these data in his criticism of our revision of the Two Rivers Till boundary in spite of the fact that they clearly support our hypothesis.

Thus, our modification of the Two Rivers limit of Lineback et al. (1974, Fig. 5) is based on our reinterpretation of a single data point, a reinterpretation that is supported by three separate lines of evidence and that we believe is fully justified.

Black is correct in pointing to the error on p. 418. A line of type was dropped in the final preparation of the manuscript and an ERRATUM was published in Quaternary Research (Vol. 7, No. 3, p. 428) prior to Black's reference to our "anachronistic statement.'

Black continues to argue that Lake 


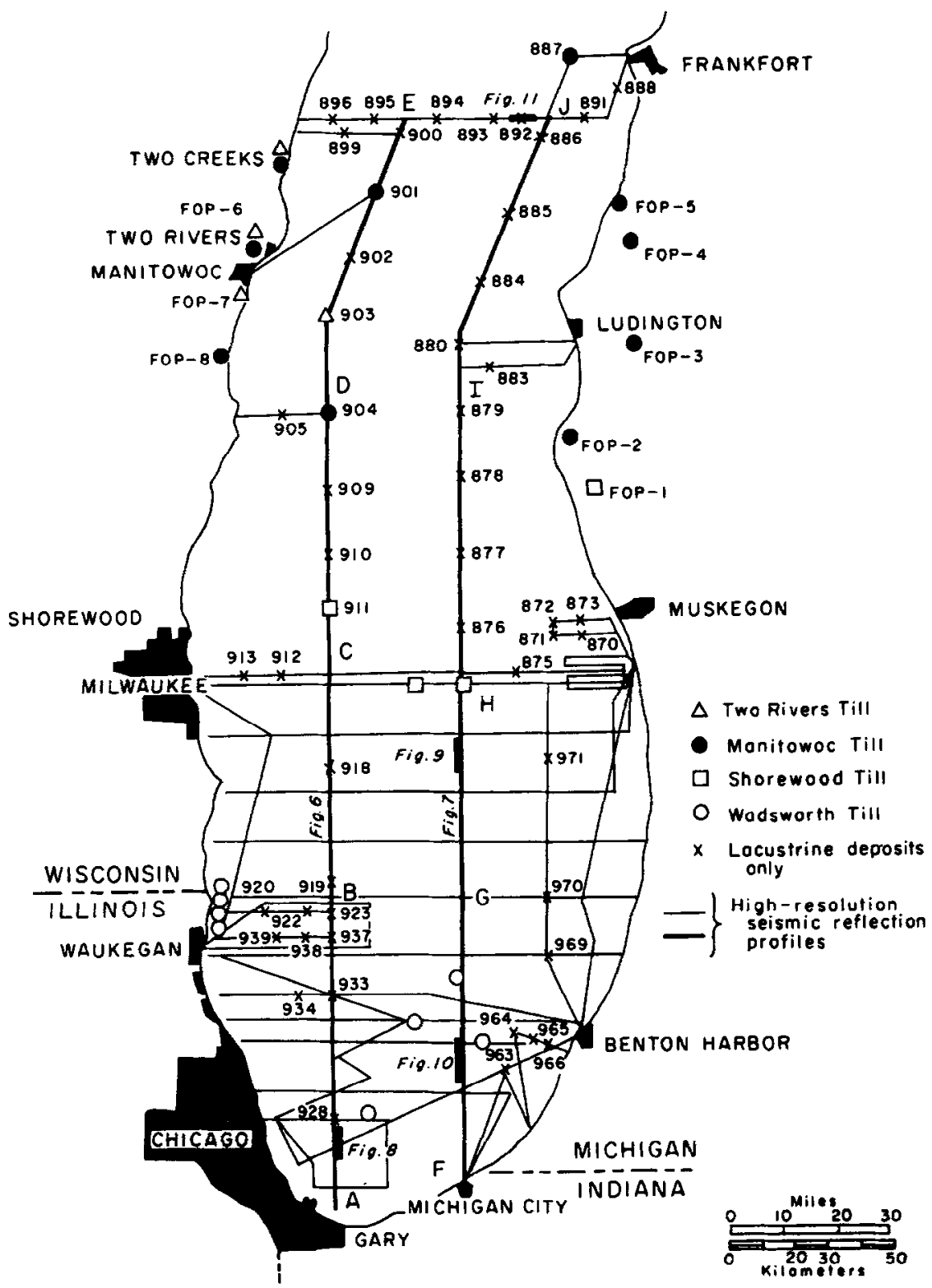

FIG. 1. Location of samples discussed in text and location of cores, cross sections, and onshore till samples used in the construction of Fig. 1 of Black (1978) (Fig. 5, Lineback et al., 1974). [Figure 4 from I ineback et al. (1974). Reprinted by permission.]

Michigan Lobe Greatlakean ice traversed the Twin Rivers lowland and deposited the upper (red) till at the Valders type locality. He has no evidence for this argument, and our data indicate that this is not the correct interpretation. Black seems to ignore the depth of leaching data and power auger information presented by Mickelson and Evenson (1975).
Black asks "why the post-Twocreekan ice in the massive Lake Michigan Lobe terminated 25 miles north of, and many hundred feet lower than ice of the much smaller Green Bay Lobe." First of all, arguments based on minor lobal asymmetry are not likely to provide definitive answers and certainly cannot be used to argue against the hypothesis of Evenson et al. 


\section{TABLE 1}

Composition of Onshore Tills Near lake Michigan and at the Twocreekan TyPe Locality at Two Creeks, Wisconsin ${ }^{a}$

\begin{tabular}{lcccccccc}
\hline & $\begin{array}{c}\text { Calcite } \\
\text { (counts/ } / \\
\mathrm{sec})\end{array}$ & $\begin{array}{c}\text { Dolomite } \\
\text { (counts/ } \\
\mathrm{sec})\end{array}$ & $\begin{array}{c}\text { Expand- } \\
\text { ables } \\
(\%)\end{array}$ & $\begin{array}{c}\text { Illite } \\
(\%)\end{array}$ & $\begin{array}{c}\text { Chlorite } \\
(\%)\end{array}$ & $\begin{array}{c}\text { Vermiculite } \\
\text { (relative } \\
\text { amount) }\end{array}$ & $\begin{array}{c}\text { Color of } 2 \mu \\
\text { fraction }\end{array}$ & $\begin{array}{c}\text { Number } \\
\text { of samples } \\
\text { from } \\
\text { onshore }\end{array}$ \\
\hline Two Rivers Till & 56 & 38 & 27 & 52 & 21 & High & Reddish brown & 2 \\
FOP-7 & 65 & 63 & 18 & 58 & 28 & & & 1 \\
Manitowoc Till & 57 & 79 & 24 & 55 & 21 & High & Reddish brown & 12 \\
\hline
\end{tabular}

a Modified from Table 1 of Lineback et al. (1974). Used by permission.

b Adjusted for the removal of FOP-7 from the group.

c From Lineback (pers. commun., 1977).

(1976a). However, there may be a simple answer to Black's question, and the answer may come from his own work (Black, 1976). If the dotted line presented by Black (1976, Fig. 1) is accepted as "a possible modification or recessional moraine of the Valderan (Greatlakean) border"' (Black, 1976; italics ours) and is extended across the northern end of Lake Winnebago to join the boundary of Two Rivers Till (Mickelson and Evenson, 1975), then the objection of Black is resolved. This boundary appears to be in harmony with the radiocarbon dates on material under till reported by Black (196768; 1976) and by Mickelson and Evenson (1975). Although we do not currently propose this as the definitive Greatlakean border, it is a hypothesis that harmonizes our observations with those of Black (1976) and it therefore warrants further attention.

Finally, Black wonders why, in spite of the fact that we ascribe the till at Valders to the Green Bay Lobe, we ask which of the pre-Twocreekan red tills in the Lake Michigan basin is correlative with the type-Valders Till. Our reasons for ascribing a Green Bay Lobe source to the till at Valders are reviewed in Mickelson and Evenson (1975) and need not be repeated here. When we asked which till in the Lake Michigan basin was its "correlative," we meant just that, not "which till was it continuous with"; certainly till units need not be continuous and/or from the same ice lobe to be correlated.
We agree with Black's statement (1976, p. 93) that "few of the corner stones of the Quaternary geology of the region will remain unmodified, at least in detail, in the years ahead," and we respect his right to act as the "devil's advocate" in a period when the conclusions of the previous workers, including himself, are being questioned.

\section{REFERENCES}

Black, R. F. (1974). Late Pleistocene shorelines and stratigraphic relationships in the Lake Michigan Basin: Discussion. Geological Society of America Bulletin 85, 659-660.

Black, R. F. (1976). Quaternary geology of Wisconsin and contiguous upper Michigan. In "Quaternary Stratigraphy of North America" (W. C. Mahaney, ed.), pp. 93-117. Dowden, Hutchinson, and Ross, Stroudsburg, $\mathrm{Pa}$.

Black, R. F. (1978). Comment on "Greatlakean Substage: A replacement for Valderan Substage in the Lake Michigan basin" by E. B. Evenson, W. R. Farrand, D. F. Eschman, D. M. Mickelson and L. J. Maher, Quaternary Research 9, 116-118.

Black, R. F., and Rubin, M. (1967-68). Radiocarbon dates of Wisconsin. Wisconsin Academy of Science, Arts and Letters 56, 99-115.

Dreimanis, A., and Goldthwait, R. P. (1973). Wisconsin glaciation in the Huron, Erie, and Ontario Lobes. In "The Wisconsinan Stage" (R. F. Black, R. P. Goldthwait, and H. B. Willman, Eds.) pp. 71-106, Geological Society of America Memoir 136.

Evenson, E. B. (1973). Late Pleistocene shorelines and stratigraphic relations in the Lake Michigan Basin. Geological Society of America Bulletin 84, 2281-2298.

Evenson, E. B., Farrand, W. R., and Eschman, D. F. (1974). Late Pleistocene shorelines and stratigraphic 
relations in the Lake Michigan Basin: Reply. Geological Society of America Bulletin 85, 661-664.

Evenson, E. B., and Dreimanis, A. (1976). Late Glacial $(14,000-10,000$ years B.P.) history of the Great Lakes region and possible correlations. In "Quaternary Glaciations in the Northern Hemisphere, Report No. 3, Bellingham, Washington" (D. J. Easterbrook, V. Sibrava, Eds.) pp. 217-238. Bellingham, Washington and Prague.

Evenson, E. B., Farrand, W. R., Eschman, D. F., Mickelson, D. M., and Maher, L. J. (1976a). Greatlakean substage: A replacement for Valderan Substage in the Lake Michigan Basin. Quaternary Research 6, 411-424.

Evenson, E. B., Mickelson, D. M., and Farrand, W. R. (1976b). Stratigraphy and correlation of the late Wisconsin glacial events in the western Great Lakes

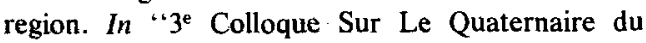
Quebec Résumès," pp. 26-27.

Evenson, E. B., Mickelson, D. M., and Farrand, W. R. (in press). Stratigraphy and correlation of the late Wisconsinan glacial events in the Lake Michigan Basin. Paléo-Québec.

Farrand, W. R., Zahner, R., and Benninghoff, W. S. (1969). "Cary-Port Huron Interstade: Evidence from a buried bryophyte bed, Sheboygan County, Michigan," pp. 249-262. Geological Society of America, Special Paper 123.

Frye, J. C. and Willman, H. B. (1960). Classification of the Wisconsin Stage in the Lake Michigan Glacial Lobe. Illinois Geological Survey Circular 285.

Frye, J. C., Willman, H. B., Rubin, M., and Black, R. F. (1968). Definition of Wisconsin Stage. United States Geological Survey Bulletin 1274-E.

LaSalle, P., and Elson, J. A. (1975). Emplacement of the St. Narcisse moraine as a climatic event in eastern Canada. Quaternary Research 5, 621-625.

Lineback, J. A., Gross, D. L., and Meyer, R. P. (1974). Glacial tills under Lake Michigan. Illinois Geological Survey Environmental Geology Note 69.

Mickelson, D. M., and Evenson, E. B. (1975). PreTwocreekan age of the type Valders till, Wisconsin. Geology 3 (No. 10), 587-590.

Mickelson, D. M., et al., (1977). "Shoreline Erosion and Bluff Stability Along Lake Michigan and Lake Superior Shorelines of Wisconsin." Wisconsin Coastal Management Program, Wisconsin State Planning Office.

Occhietti, S. (1972). Moraine de poussée Valders (Dryas III) à Saint-Narcisse, Quebec. In " $22^{\mathrm{e}}$ Congrès international de Geographie. Montréal." La Géographie International, T. 1, pp. 117-119.

Occhietti, S. (1974). Dépots et Faits Quaternaires du Bas-Saint-Maurice, Quebec, Geological Survey of Canada, Paper 74-1, part B, p. 217.

Occhietti, S. (1976). Dépots et Faits Quaternaires du Bas-Saint-Maurice, Quebec ( $2^{\mathrm{e}}$ partie), Geological Survey of Canada, Paper 76-1C, pp. 217-220.

Prichonnet, G. (1976). Deglaciation of the St. Lawrence Valley in the Montreal Area and Synchronous Ice Invasion. In " $3^{\mathrm{e}}$ Colloque Sur Le Quaternaire du Quebec Résumés," p. 82.

Terasmae, J., and LaSalle, P. (1968). Notes on late-glacial palynology and geochronology at St. Hilaire, Quebec. Canadian Journal of Earth Science 5, 249-257.

Willman, H. B., and Frye, J. C. (1970). Pleistocene stratigraphy of Illinois. Illinois Geological Survey Bulletin 94.

EDWARD B. EvENSON Department of Geological Sciences Lehigh University Bethlehem, Pennsylvania 18015

William R. Farrand and Donald F. EschMan Department of Geology and Mineralogy University of Michigan Ann Arbor, Michigan 48104

David M. Mickelson AND LOUIS J. MAHER

Department of Geology and Geophysics University of Wisconsin Madison, Wisconsin 53706

\section{Peopling of the Americas: A Reply to Irving Rouse}

Rouse's article (1976) contains several misstatements or misunderstandings of my position on early man in the Americas. He writes, for example, "Lynch concludes that the Paccaicasa and Ayacucho deposits represent a single complex contemporaneous with his Guitarrero complex and that his charcoal based date of $12,560 \pm 360$ applies to both of them" (p. 602). This is untrue.
A careful reading of my papers would show that I have not applied the earliest, and to me rather awkward, date from Guitarrero to collections made $500 \mathrm{~km}$ away by another archaeologist. Nor have I said that they were contemporaneous with the Guitarrero complex. To attribute arbitrarily one of the five dates from Guitarrero I to MacNeish's material from Pikimachay would make me 